\title{
PRANATA-PRANATA SOSIAL DALAM MASYARAKAT PANTAI DI SULAWESI SELATAN*
}

Oleh :

\section{A. Sallatang dan H. Walinono}

Pranata-pranata sosial terdapat di setiap masyarakat. Ia mcrupakan pcrangkat normanorma bcrkcnaan dengan masalah-masalah pokok yang bersifat tetap dan universal untuk kehidupan sosial yang teratur.

Paling sedikit ada tiga unsur pada setiap pranata sosial. Ketiga unsur tcrmaksud, adalah: (a) pola-pola tertcntu tingkah laku yang melembaga, (b) pengaturan tingkah laku individu-individu menurut pola-pola itu dan (c) keleraturanketeraturan tertcntu yang ditunjang oleh normanorma dengan sanksi-sanksi atau pun ganjaran yang disahkan oleh norma-norma itu. 1)

Pranata-pranata mcrupakan prinsip-prinsip yang mengatur dan mengorganisasikan hubungan-hubungan manusia di dalam masyarakat ke dalam suatu atau beberapa pola tertentu, berkenaan dengan masalah-masalah pokok atau masalah-masalah yang mcnyangkut kebutuhan pokok dalam berbagai bidang.

Menurut bidang atau ruang 1 ingkup kepranataan, jenis-jcnis pranata sosial yang ada, antara lain adalah pranata-pranata keluarga dan kekerabatan, pendidikan, ekonomi dan polilik.2)

Norma-norma yang merupakan isi dari suatu jenis pranata yang sama, dapat bcrbeda antar masyarakat. Variasi itu berkaitan dengan banyak faktor. Akan tetapi, di antaranya yang mungkin sangat eral kaitannya, adalah faktor nilai-nilai (values) yang ada dalam masyarakat yang bersangkutan.
Dikatakan demikian, karena norma-norma adalah perincian atau konkritisasi dari nilainilai.

Selain faktor nilai, juga jenis-jenis fasilitas alam fisik3) Daerah di mana masyarakat yang bersangkutan berada, mungkin turut membawa variasi itu. Hal ini terutama jika diingat bahwa pranata-pranata sosial. erat kaitannya dengan masalah-masalah yang menyangkut kebutuhan pokok masyarakat, sedang kebutuhan-kebutuhan pokok masyarakat, lebih lanjut berkaitan dengan jenis-jenis fasilitas yang ada atau tersedia di daerah itu.

Beberapa pranata yang ada di masyarakat pantai Sulawesi Selatan yang erat kaitannya dengan fasilitas-fasilitas yang tersedia pada alam fisik daerah pantai, antara lain adalah pranata pcmbuatan perahu, pranata pelayaran dan pranata penangkapan ikan. Pranata-pranata ini diwujudkan oleh kclompok-kelompok sosial yang ada di masyarakat pantai khususnya oleh kelompok-kelompok pembuatan perahu, kelompok-kelompok pelayaran dan kelompok-kelompok penangkapan ikan atau kclompok-kelompok nelayan.4)

Pranata-pranata tersebut di atas merupakan pranata ekonomi atau mempunyai lingkungan ulama di bidang itu. Kelompok-kelompok yang terutama mewujudkannya scperti disebutkan di atas, merupakan kelompok-kelompok kerja.

Kelompok-kelompok scrupa ini dikenal dalam

\footnotetext{
* Dosen Fakultas Pertanian UNHAS dalam mata pelajaran Sosiologi Pembangunan Masyarakat Tani. Guru Besar Sosiologi Politik Fakulias Ilmu Sosial dan Ilmu Polilik UNHAS dan Rektor Universitas Ilasanuddin.
} 
masyarakat dengan pemimpinnya yang disebut ponggawa (Bugis)5 dengan para pengikutnya disebut Sawi. Baik pada kelompok Pembuat perahu, Pelayaran dan Penangkapan ikan, maupun kelompok-kelompok lainnya. Karena itu kami cenderung menamakan kelompok Ponggawa-Sawi.6)

Norma-norma yang melembaga di dalam masyarakat dan terwujud sebagai pranatapranata, diperkirakan terutama bersumber dari aturan-aturan adat.7) Baik pranata pembuatan perahu dan pranata pelayaran, maupun pranata penangkapan ikan.

Aturan-aturan adat di Sulawesi Selatan, khususnya bagi masyarakat Bugis dan Makassar, ada yang tercatat di dalam lontaraklontarak. Dalam bidang kehidupan sosial masyarakat pantai, misalnya Adek Allopi-loping Bicaranna PabbalukE yang konon ditulis oleh Amanna Gappa pada abad ke-17 (1667). Lontarak ini berisikan aturan-aturan adat untuk pelayaran dan perdagangan.8)

Dalam perincian, pranata-pranata nampaknya terdiri atas bahagian-bahagian yang merupakan norma-normaatau perangkat norma-norma yang merupakan isi bagi pranata.

Pranata pembuatan perahu, meliputi normanorma yang antara lain mengatur bagaimana permufakatan antara pembuat perahu dengan pemesan harus dilakukan, bagaimana pelaksanaan pembuatan perahu harus dilakukan dan bagaimana pembayaran harus dilakukan.

Demikian pula dengan pranata-pranata pelayaran dan penangkapan ikan serta pranatapranata lainnya, dapat diperincikan ke dalam bahagian-bahagian. Bahagian-bahagian itu berkaitan satu sama lain, saling menguatkan atau saling menunjang atau terintegrasikan dan secara keseluruhan merupakan satu kesatuan. Bahkan pranata yang satu berkaitan dengan pranata-pranata lainnya.
Ada norma yang mengatur bahwa perahu yang seharusnya dan biasanya diserahkan oleh pembuat perahu (ponggawa kelompok pembuat perahu) kepada pemesan (ponggawa kelompok pelayaran atau ponggawa kelompok nelayan) adalah perahu dalam bentuk "batang-tubuh" saja (belum mempunyai alat-alat perlengkapan berlayar, yaitu tanpa tiang layar, layar, kemudi, talitemali dan sebagainya). Adalah keharusan dan biasanya memang demikian, pemesan sendiri yang mengusahakan atau memperlengkapi perahu itu sampai dapat dilayarkan.

Karena pemesan adalah kelompok (kelompok pelayaran atau kelompok penangkapan ikan), makapekerjaan ini merupakan pekerjaan kelompok yang bersangkutan. Berkenaan dengan itu, ada norma yang mengatur bahwa ponggawa kelompok yang bersangkutan menyediakan biaya untuk pekerjaan-pekerjaan itu dan yang melaksanakannya adalah nakhoda atau juragang dan jurumudi bersama sawi lainnya. Baik pada kelompok pelayaran, maupun pada kelompok penangkapan ikan atau kelompok nelayan.

Dalam pelaksanaan pekerjaan berlayar mencari dan menemukan muatan bagi kelompok pelayaran atau mencari dan menemukan lokasi penangkapan ikan yang baik bagi kelompok nelayan, ada norma-norma yang mengatur tingkah laku mana yang pan tang dan yang harus dilakukan dalam situasi tertentu. Nampaknya pantangan-pantangan dan keharusan-keharusan itu dipertalikan dengan kepercayaan-kepercayaan dan ditujukan untuk melindungi atau menghindari kelompok dari kesukaran dan kegagalan atau malapetaka.

Lebih lanjut mengenai hal di atas, ada normanorma yang mengharuskan bahwa ponggawa dan nakhoda atau juragang yang merupakan ponggawa kecil di dalam kelompok, lebih mengetahui dan lebih menghayatinya. Demikian pula halnya dengan pengetahuan-pengetahuan Iain- 
nya untuk kcselamatan pelayaran dan tugas kclompok pada umumnya.

Untuk mclakukan tugas kciompok, ada norma-norma yang mengatur pembahagian pcranan di dalam kelompok, Seianjutnya, ada norma-norma yang mengatur bagaimana hasii yang dipcrolch kclompok tcrbagi ke setiap anggota. Nampaknya hal ini didasarkan atas peranan atau perangkat peranan masingmasing.

Peranan atau perangkat peranan ponggawa, mengorganisasikan kelompok, mcnycdiakan modal, mengerahkan kelompok dan melakukan pcmasaran hasil memperolch bahagian hasil lebih bcsar di banding dengan setiap orang sawi yang mcmbantunya. Akan tetapi jika bahagian hasii yang dipcrolch sescorang ponggawa dalam suatu kclompok kerja yang diponggawainya di bandmg dengan bahagian hasii yang diperolch scluruh sawi pada kelompok itu, berkisar setengah dari scluruh hasil bersih yang dihasilkan olch kelompok yang bcrsangkutan dalam masyarakat nelayan ji dacrah ini, 9)

Rclatif lebih besarnyapendapatan ponggawa dalam masyarakat nelayan di daerah ini, erat kaitannya dengan banyaknya kelompok-kelompok kcrja yang berukuran kecil yang diponggawai olehnya.10) Katakanlah, lebih banyaknya bcrpcranan sebagai ponggawa.

Berkenaan dengan peranan mengorganisasikan kelompok, ada norma-norma yang mengatur perekruian anggota atau sawi. Mercka yang harus dan biasanya tcrekrul menjadi sawi untuk suatu musim (bagi kelompok pelayarar. dan kclompok penangkapan ikan) atau suatu pekerjaan (bagi kelompok pembuat pcrahu), biasanya adalah yang lebih banyak bertingkah laku sesuai dengan norma-norma yang diperlukan dalam kelompok.

Nampaknya, norma-norma dalam kelompok pada pokoknya merupakan pcrincian atau konkrittuasi dari suatu nilai (value) yang ada dalam sistem sosiai dan sistem budaya di daerah ini, yaitu sirik.1 1) Nilai ini kami coba namakan "rasa-harga-diri", walaupun mungkin istilah ini tak dapat meiukiskan scluruh maknanya.

Mcreka yang bertingkah laku menurut noimanorma yang dipcrlakukan dalam keiompok, dipandang baik. Demikian, karena mcreka itu dipandang menjaga atau melindungi sirik atau atau rasa-harga-diri dan nama baik ponggawa scrta sesama anggota. Karena itu mercka inilah yang dilempalkan pada prioritas ncrtama untuk direkret.

Seseorang yang iebih banyak bertingkah laku sesuai dengan norma-norma, ditambah dengan faktor-faktor lainnya, ada Kalanya mempunyai sisa panjar karcr.a akumulasi panjarnya leb'h besar, sehingga yang terekrut setiap kali nampak seolah-olah diutamakan kepada mereka yang mempunyai sisa panjar. Tentu saja sisa panjar merupakan faktor yang turut menguatkan ke arah itu. Namun, perkaranya adalah kepatuhan kepada norma-norma di dalam kelompok.

Dalam hal pcrekrutar, anggota sawi yang baru, ada norma yang mengutamakan anggotaanggota kcrabat atau orang lain yang dipcrlakukan seolah-olah kerabat dari sescorang anggota kclompok. Lebih senng terjadi, anakanak laki-laki para sawi telah mulai ikut-ikut dalam kelompok scjak masih duduk di bangku Sekolah Dasar 12) dan akhirnya ia menjadi sawi.

Di antara ponggawa, ada yang ditinggalkan olch kebanyakan anggota atau sawinya. Ponggawa yang demikian, mungkin sekali tidak mampu mcmpcrtahankan status dan peranannys sebagai ponggawa.

Jika untuk para sawi ada norma yang mengatur agar mereka menjaga atau melindungi sirik atau rasa-harga-diri ponggawa, maka ada pula norma yang tuntutannya lebih besar kepada ponggawa, untuk melindungi sirik atau rasa- 
harga-diri para sawinya.

Lebih lanjut, perlindungan seseorang ponggawakepadaparasawinyajugamenyangkut soal kemampuannya menyediakan modal (alatalat produksi) termasuk modal kerja yang disebut panjar. Katakanlah, kemampuannya untuk membuka lapangan dan kesempatan kerja bagi para sawi termasuk kerabat para sawi. Tetapi juga, sekaligus merupakan kemampuan ponggawa menyerap kecemasan mereka akan kctiadaan kerja atau menganggur. Bahkan kecemasan untuk tidak tertolong jika ada paceklik atau keperluan mendadak yang biasanya dinilai bersifat konsumptif. Hal ini semua berkaitan dengan panjar-panjar kerja yang biasanya diberikan oleh ponggawa kepada para sawi.

Nampaknya, sudah merupakan kebiasaan dalam masyarakat pantai di daerah ini, jika ada pekerjaan, harus ada panjar. Di mana ada kerja, di situ ada panjar.

Selain dari kemampuan ponggawa yang telah disebutkan di atas, juga adalah kemampuannya meningkatkan pengetahuan para anggotanya. Biasanya, seseorang anggota yang tclah berada pada tingkat yang meyakinkan untuk ditampilkan sebagai ponggawa untuk waktu yang tidak lama kemudian, iadiberikan kesempatan dalam kelompok untuk memainkan peranan membantu ponggawa di bidang pemasaran.

Norma-norma yang dikemukakan di atas, merupakan isi pranata-pranata sosial dalam bidang pembuatan perahu, pelayaran dan penangkapan ikan yang merupakan pranata-pranata ekonomi.

Sebagai pranata-pranata yang mempunyai lingkungan utama kepranataan yang terletak di bidang ekonomi yang berisikan norma-norma yang menyangkut lapangan dan kesempatan kerja serta perkreditan, tetapi juga bertalian erat dengan bidang pendidikan dan proses sosialisasi pada umumnya serta bidang-bidang lainnya dalam masyarakat pantai di daerah ini.

Norma-norma yang merupakan isi dari pranata tersebut, merupakan perincian dari atau katakanlah berakar pada sebuah nilai, yaitu Sirik. Nilai yang dianut oleh orang-orang Bugis-
Makassar yang sejak dahulu telah mendiami pesisir pantai di daerah ini. Pranatanya, dapat kita sebut pranata keponggawaan.

Dalam siluasi-situasi penting, tidak jarang terdengar adanya pernyataan sawi kepada ponggawanya bahwa keikutsertaannya dalam kelompok, hanyalah untuk sirik atau rasa-hargadirinya. Demikian pula, sebaliknya oleh ponggawa kepada para sawi.

Norma-norma tersebut di atas pada umumnya masih ditaati Juga, kelompok-kelompok kerja yang memperlakukan norma-norma itu tetap ada dan bertahan hidup.

Ketaatan orang kepada norma-norma tersebut, mungkin tidak hanya karena kebiasaan, tetapi terutama karena adanya pengawasan sosial dengan sanksi-sanksi dan ganjaran. Sanksi berupa celaan atau cemohan kepada mereka yang melakukan penyimpangan-penyimpangan dan ganjaran berupa pujian dan pengakuan kepada mereka yang mentaatinya.

Norma-norma ini diwariskan dari generasi yang satu kegenerasi berikutnya sejak dahulu. Pewarisan ini tetap berlangsung sampai sekarang. Karena itu ponggawa dan pranata keponggawaan masih akan ditemukan di masa datang. Tentu saja dengan harapan agar ponggawa dan pranata keponggawaan yang lebih baik atau lebih tinggi kualitasnya daripada apa yang ada sekarang.

Bagaimana pun, ponggawa dan pranata keponggawaan merupakan potensi yang nyata ada di dalam masyarakat pantai padadewasa ini.

Ponggawa dan kelompoknya merupakan potensi sumber manusia dan potensi sosial yang sebaiknyadigunakan, daripada tidak. Bagaimana pun, para ponggawa merupakan wiras wasta yang nyata ada di desa. Kebutuhan akan wiras wasta di desa untuk pengembangan ekonomi dan masyarakat desa, mungkin potensi ini dapat dipertimbangkan. Kebutuhan akan wiraswasta yang sesuai dengan tuntutan perkembangan, tidak mustahil dapat dipenuhi dengan pengembangan para ponggawa ke arah itu, melalui berbagai bimbingan di bidang yang bersangkutan masing-masing. 